\title{
Correlation analysis of the relationship between B-type natriuretic peptide and selected echocardiographic parameters in patients with permanent pacemakers
}

\section{Analiza korelacji pomiędzy peptydem natriuretycznym typu B a wybranymi parametrami echokardiograficznymi u pacjentów po wszczepieniu stymulatora serca na state}

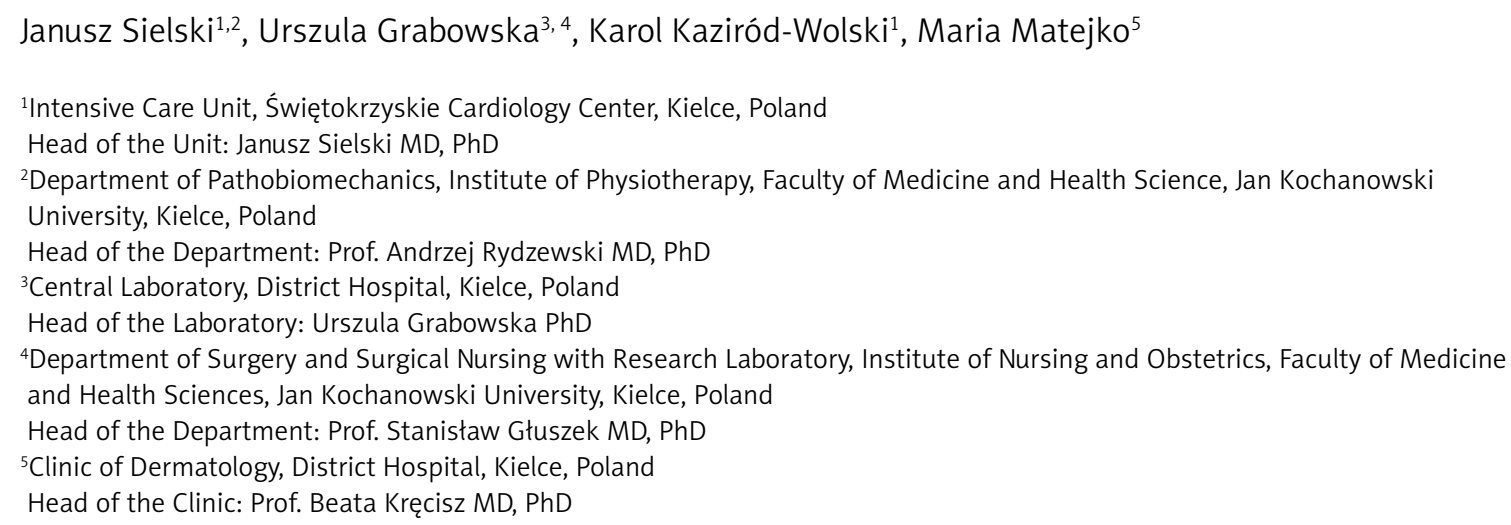

Key words: B-type natriuretic peptide, cardiac pacing, left atrial volume index.

Słowa kluczowe: peptyd natriuretyczny typu B, stymulacja serca, indeks objętości lewego przedsionka.

\begin{abstract}
Introduction: The present study was undertaken to evaluate the practical value of BNP measurements and echocardiographic left ventricular volume index in patients with permanent pacemakers because there are no such reports in the literature.

Aim of the research: The aim of the study was to reveal multiple correlations between BNP levels and selected echocardiographic parameters of the left atrium in patients with permanent pacemakers. In the literature there are reports on the significance of BNP values and left atrial size in patients with permanent pacemakers. The results of the present study appear to be of value in the outpatient assessment of these patients.

Material and methods: We analysed a group of 117 patients with permanent pacemakers (AAI/R 21 patients, DDD/R 59 patients, VVI/R 37 patients) and 48 healthy volunteers serving as the control group. BNP measurements were performed on venous blood samples using Triage meters. The Simpson method and the ellipse method were used to assess the left atrium on echocardiography.

Results: There was a significant correlation between BNP and maximum left atrial volume, minimum left atrial volume, and left atrial volume index in patients with $\mathrm{AAI} / \mathrm{R}, \mathrm{DDD} / \mathrm{R}$, and $\mathrm{VVI} / \mathrm{R}$ pacemakers at 3 and 6 months after the implantation.

Conclusions: In patients after implantation of permanent pacemakers there are correlations between BNP values and echocardiographic left atrial parameters, especially in patients with DDD/R pacemakers. Left atrial function improves in patients with DDD/R pacemakers. Pacemaker check-up should be extended to include BNP measurements and echocardiographic assessment of the left atrium.
\end{abstract}

\section{Streszczenie}

Wprowadzenie: Przeprowadzono badania dotyczące przydatności praktycznej oznaczania peptydu natriuretycznego typu B (BNP) i badania echokardiograficznego wykorzystującego indeks objętości lewego przedsionka u chorych po wszczepieniu stymulatora serca na stałe. 
Cel pracy: Celem przeprowadzonych badań było określenie korelacji pomiędzy BNP a wybranymi parametrami oceny echokardiograficznej lewego przedsionka u chorych po implantacji kardiostymulatora. W piśmiennictwie dostępne są prace dotyczące stymulacji stałej serca, wartości BNP po implantacji stymulatora oraz oceny echokardiograficznej lewego przedsionka. Również przeprowadzone badania własne wydają się potwierdzać znaczenie tych parametrów w ambulatoryjnej ocenie tej grupy chorych.

Materiał i metody: Przeanalizowano grupę 117 pacjentów ze wszczepionym stymulatorem serca na stałe (AAI/R 21 pacjentów, DDD/R 59 i VVI/R 37) oraz 48 zdrowych ochotników, stanowiących grupę kontrolną. Oznaczano BNP z próbki krwi żylnej za pomocą odczynników firmy Triage. Wykonywano badanie echokardiograficzne z oceną lewego przedsionka, wykorzystując metodę Simpsona i metodę elipsy.

Wyniki: Stwierdzono statystycznie istotne współczynniki korelacji pomiędzy BNP a objętością maksymalną lewego przedsionka, objętością minimalną lewego przedsionka i indeksem objętości lewego przedsionka w grupach AAI/R, DDD/R oraz VVI/R w ciągu 3 oraz 6 miesięcy po wszczepieniu stymulatora serca na stałe.

Wnioski: W trakcie obserwacji pacjentów po wszczepieniu stymulatora serca na stałe wykazano korelacje pomiędzy wartością BNP a parametrami echokardiograficznymi lewego przedsionka, szczególnie w grupie DDD/R. Po wszczepieniu stymulatora serca na stałe poprawiają się parametry czynności lewego przedsionka w grupie DDD/R. Kontrola chorych po implantacji kardiostymulatora może być wzbogacona o oznaczania BNP oraz wykonanie badania echokardiograficznego z oceną lewego przedsionka.

\section{Introduction}

Currently, in clinical practice five types of biomarkers can be identified and measured: neurohormonal biomarkers, biomarkers of myocardial injury, inflammatory biomarkers, biomarkers of organ dysfunction, and nonspecific laboratory markers. Neurohormonal biomarkers include natriuretic peptides (ANP, BNP, CNP, and other peptides), markers related to the renin-angiotensin-aldosterone system, and vasopressin [1].

Measurements of B-type natriuretic peptide (BNP) and $\mathrm{N}$-terminal pro-B-type natriuretic peptide contribute significantly to the assessment and stratification of risk in dyspnoeic patients admitted to the Intensive Coronary Care Unit and Emergency Department $[2,3]$. The levels of peptides help to differentiate patients with dyspnoea. It is extremely important to differentiate respiratory dyspnoea from dyspnoea of cardiac origin, which is a sign of new or worsening heart failure. High levels of natriuretic peptides in the blood are characteristic of cardiac dyspnoea. Each patient with dyspnoea admitted to the Emergency Department undergoes physical examination, chest X-ray, ECG recording, and BNP measurements. A BNP level below $100 \mathrm{pg} / \mathrm{ml}$ indicates no heart failure (probability $<2 \%$ ). A BNP levels between 100 and $400 \mathrm{pg} / \mathrm{ml}$ and a positive history of heart failure indicate a probability of heart failure of about $75 \%$. A BNP level that is elevated above $400 \mathrm{pg} / \mathrm{ml}$ means that the probability of heart failure and cardiac origin of dyspnoea is above 95\% [4-7]. Elevated BNP in the blood positively correlates with the prognosis and NYHA class, intraventricular pressure, and pulmonary artery pressure, whereas it negatively correlates with cardiac output $[8,9]$.

The left atrium performs three basic functions: it serves as a reservoir of blood received from pulmonary veins, a conduit for blood flowing to the left ventricle, and a booster pump compensating left ven- tricular systolic function loss [10-12]. Left atrial remodelling and adaptation occur as a result of various factors. The best-known factor for atrial remodelling is tachycardia as well as volume and pressure overload [13]. Left atrial assessment is based on a variety of echocardiographic parameters such as planimetric indices, and volume and functional parameters. Most of the parameters are widely studied in clinical trials [13, 14]. The most important planimetric indices include maximum and minimum volumes of the left atrium. In clinical practice, left atrial volume index (LAVI) is the most frequently used for atrial assessment. It is a derivative of left atrial volume indexed to body surface area. In adults the normal LAVI is $22 \pm 6 \mathrm{ml} /$ $\mathrm{m}^{2}$ [15]. The Simpson method and the ellipse method are recommended by the American Heart Association as the most useful for chamber quantification [15]. The LAVI may be significantly elevated in a variety of conditions. It is most frequently increased in atrial fibrillation, brain stroke, coronary artery disease, heart failure, renal failure, and diabetes mellitus [16-23].

\section{Aim of the research}

Studies on health problems in patients with permanent pacemakers are scarce. It is still not clear whether such directions of studies are warranted from a practical perspective. The present paper is an attempt to provide answers to some questions, especially from the viewpoint of the usefulness of BNP measurements in relation to left atrial echocardiographic parameters.

\section{Material and methods}

We analysed a group of 117 patients with permanent pacemakers, and healthy volunteers serving as the control group. The study population was divided into four groups: group I - 21 patients with an AAI/R pacemaker, group II - 59 patients with a DDD/R pacemaker, group III - 37 patients with a VVI pacemaker, 
Table 1. Clinical characteristics of the study

\begin{tabular}{|c|c|c|c|c|}
\hline Parameter & Group I (AAI/R) & Group II (DDR/R) & Group III (VVI/R) & Value of $p$ \\
\hline Age & $72.4 \pm 7.7$ & $73 \pm 7.94$ & $74.11 \pm 7.14$ & \\
\hline Gender (F/M) & $12 / 9$ & $30 / 29$ & $17 / 20$ & \\
\hline \multicolumn{5}{|l|}{ Medical history: } \\
\hline Arterial hypertension & 16 & 50 & 21 & $<0.05$ \\
\hline Coronary artery disease & 14 & 35 & 19 & $>0.05$ \\
\hline $\begin{array}{l}\text { Previous myocardial } \\
\text { infarction }\end{array}$ & 5 & 11 & 8 & $>0.05$ \\
\hline $\begin{array}{l}\text { Compensated heart } \\
\text { failure }\end{array}$ & 8 & 16 & 20 & $<0.05$ \\
\hline Diabetes mellitus & 9 & 16 & 9 & $>0.05$ \\
\hline $\begin{array}{l}\text { Previous transient } \\
\text { ischemic attack }\end{array}$ & 4 & 5 & 4 & $>0.05$ \\
\hline \multicolumn{5}{|l|}{ Medication: } \\
\hline ACE & 15 & 40 & 30 & $>0.05$ \\
\hline ARB & 4 & 11 & 4 & $>0.05$ \\
\hline$\beta$-Blockers & 14 & 28 & 27 & $<0.05$ \\
\hline Ca blockers & 3 & 12 & 7 & $>0.05$ \\
\hline Diuretics & 5 & 18 & 3 & $>0.05$ \\
\hline Nitrates & 5 & 3 & 1 & $>0.05$ \\
\hline Statins & 12 & 22 & 22 & $>0.05$ \\
\hline Antidiabetic agents & 9 & 9 & 9 & $>0.05$ \\
\hline Anticoagulants & 4 & 28 & 28 & $>0.05$ \\
\hline
\end{tabular}

and group IV - 48 volunteers with similar age without any significant health problems. Patients with acute coronary syndromes up to 6 months before the implantation of pacemakers, active inflammation, brain stroke up to 6 months before the implantation, heart defects, heart failure NYHA class III and IV, cancers, respiratory failure, connective tissue diseases, muscular dystrophy, anaemia with haemoglobin $10 \mathrm{~g} / \mathrm{dl}$ and less, and thyroid diseases were excluded from the study. Additionally, those with rates of paced beats below $75 \%$ during pacemaker check-up were not taken into account. The patients in the present study differed with respect to the presence of arterial hypertension and heart failure in the VVI/R and DDD/R groups. There were also differences in the use of certain medicines. However, there were no statistical differences in the use of angiotensin converting enzyme inhibitors and angiotensin receptor blockers. The clinical characteristics and medication use in all study groups are summarised in Table 1. Patients were assigned to group I, II, and III if they were selected for pacemaker implantation according to the current guidelines, mainly the Recommendations for Cardiac Pacing and Resynchronisation of the Polish Cardiac
Table 2. Patient selection for pacemaker implantation

\begin{tabular}{|c|c|}
\hline \multirow[t]{3}{*}{ Group I AAI/R } & $\begin{array}{l}\text { Sick sinus dysfunction with normal } \\
\text { AV node function: }\end{array}$ \\
\hline & a) sinus bradycardia \\
\hline & $\begin{array}{l}\text { b) bradycardia-tachycardia } \\
\text { syndrome }\end{array}$ \\
\hline \multirow[t]{5}{*}{ Group II DDD/R } & 1. Sick sinus dysfunction: \\
\hline & a) sinus bradycardia \\
\hline & $\begin{array}{l}\text { b) bradycardia-tachycardia } \\
\text { syndrome }\end{array}$ \\
\hline & $\begin{array}{l}\text { 2. Second-degree AV block with MAS } \\
\text { episodes }\end{array}$ \\
\hline & 3. Third-degree AV block \\
\hline \multirow[t]{2}{*}{ Group III VVI/R } & 1. Third-degree AV block \\
\hline & $\begin{array}{l}\text { 2. Atrial fibrillation with } \mathrm{AV} \\
\text { conduction disorders }\end{array}$ \\
\hline
\end{tabular}

Society published in 2007 and revised in 2010. Table 2 summarises patient selection for implantation. The study was approved by the Local Bioethics Committee (the Swietokrzyska Chamber of Physicians, ap- 
proval no. 8/2009 of 19 May 2009) and carried out between January 2010 and January 2012.

BNP measurements were performed on venous blood samples collected in EDTA and centrifuged at $2000 \mathrm{G}$ for $10 \mathrm{~min}$ to isolate plasma. Then, the samples were placed on the DXI 600 analyzer (Beckman Coulter) and the Triage meters were used for the quantitative assessment of BNP.

The Simpson method and the ellipse method, recommended by the American Heart Association [15] were used to assess the left atrium on echocardiography. The left atrial chamber is divided into a series of oval discs. The volume of the left atrium is the sum of the volumes of the individual discs. The lower atrial border is formed by the mitral valve ring. For practical reasons fundamental planimetric measurements were chosen for analysis, i.e. maximum left atrial volume $\left(\mathrm{LAV}_{\mathrm{max}} ; \mathrm{ml}\right)$ calculated according to the following formula: $\mathrm{LAV}_{\max }=\left[\varpi / 6 \times\left(\mathrm{LA}_{\max } \times \mathrm{LA}_{\text {short }} \times \mathrm{La}_{\text {long }}\right)\right] ;$ minimum left atrial volume $\left(\mathrm{LAV}_{\min } ; \mathrm{ml}\right)$ calculated according to the following formula: $\mathrm{LAV}_{\min }=\left[\varpi / 6 \times\left(\mathrm{LA}_{\min } \times\right.\right.$ $\left.\mathrm{La}_{\text {short }} \times \mathrm{LA}_{\text {long }}\right)$ ]; and left atrial volume index, which is the volume of the left atrium indexed to body surface area and expressed in $\mathrm{ml} / \mathrm{m}^{2}$. Normal LAVI was determined to be $22 \pm 6 \mathrm{ml} / \mathrm{m}^{2}$. Echocardiograms were obtained using an ACUSON SEQUOIA device and a 3.5-Mhz transducer with the patient in the left lateral decubitus position, acquiring images in the parasternal long and short axis views.

\section{Statistical analysis}

In statistical analysis Spearman correlation rankorder coefficient was calculated because of the distribution and character of variables. The coefficient is used to test the strength of the relationship between the two variables, especially qualitative variables, and to put the observations in a certain order. The measure can also be used to test the relationship between quantitative variables if the number of observations is small.

Ranking the data involves putting the values in ascending (descending) order based on a specific variable and assigning new values. The data can be ranked from the smallest to the largest value or vice versa; however, the order must be identical for the two variables. If two or more values were the same, we averaged the ranks for the tied values. If the two variables move in the same (or generally the same) direction there is a positive correlation between the variables, but when the two variables move in the opposite direction the correlation is negative.

The numerical value of rank correlation coefficient falls in the range between -1 and $+1\left(-1 \leq r_{s} \leq+1\right)$, and it is interpreted in the same way as Pearson correlation coefficient, i.e. the greater the absolute value of a correlation coefficient, the stronger the relationship between the variables.

\section{Results}

In the present study, 3 months after $\mathrm{AAI} / \mathrm{R}$ pacemaker implantation, there was a significant correlation between BNP and maximum left atrial volume $(q=0.55, t=2.89)$, minimum left atrial volume $(q=$ $0.67, t=3.93)$, and left atrial volume index $(q=0.60$, $t=3.24$ ) (Table 3 and Figure 1). At 3 months after $\mathrm{DDD} / \mathrm{R}$ pacemaker implantation there was a significant correlation between BNP and maximum left atrial volume $(q=0.39, t=3.18)$, minimum left atrial volume ( $q=0.40, t=3.34)$, and left atrial volume index $(q=0.40, t=3.29)$ (Table 3). At 6 months after $\mathrm{DDD} / \mathrm{R}$ pacemaker implantation there was a significant correlation between BNP and maximum left atrial volume $(q=0.47, t=4.03)$, minimum left atrial volume ( $q=0.49, t=4.28)$, and left atrial volume index ( $q=0.50, t=4.40)$ (Table 3 and Figure 2). At 3 months after VVI/R pacemaker implantation there was a significant correlation between BNP and maximum left atrial volume $(q=0.54, t=3.77)$, minimum left atrial volume $(q=0.59, t=4.32)$, and left atrial volume index $(q=0.56, t=4.02)$ (Table 3 and Figure 3). At 6 months after VVI/R pacemaker implantation there was a significant correlation between BNP and maximum left atrial volume $(q=0.39$, $t=2.49)$, minimum left atrial volume $(q=0.37$, $t=2.39)$, and left atrial volume index $(q=0.38, t=2.45)$ (Table 3).

\section{Discussion}

It has been 55 years since the first permanent pacemaker implantation. In 2012, 756 permanent pacemakers were implanted per million inhabitants in Poland and 923 per million inhabitants in Europe [24]. Pacemaker therapy has become a vast specialist domain in cardiology. The rapid development of cardiac pacing provided an impulse for a search for noninvasive tests to be used for the evaluation of patients with permanent pacemakers.

Recently, a number of randomised studies have been performed to assess cardiac function based on BNP measurements in patients with heart failure. Maisel et al. in 464 patients, Troughton et al. in 106 patients, and Cohen-Salal et al. in 1327 patients [25-28] demonstrated the clinical usefulness of BNP measurements to monitor patients with heart failure and to estimate their risk of dying.

There are also interesting non-randomised studies evaluating BNP in patients with permanent pacemakers. Kafkas et al. analysed 67 patients with DDD/R and VVI/R pacemakers and demonstrated significantly elevated BNP values at 30 days after the implantation. The increase was probably a result of right ventricular apex pacing. It was therefore concluded that BNP is an early marker of structural and functional myocardial changes in patients with permanent pacemakers [29]. 
Table 3. Correlation analysis of the relationship between B-type natriuretic peptide and selected echocardiographic parameters of left atrium in patients selected for AAI/R pacing at 3 months after the implantation, DDD/R at 3 and 6 months after the implantation, and VVI/R at 3 and 6 months after the implantation

\begin{tabular}{|c|c|c|c|c|}
\hline \multirow[t]{2}{*}{ Variables } & \multicolumn{4}{|c|}{ B-type natriuretic peptide in pg/1000 $\mu \mathrm{l}$} \\
\hline & No. of patients & Spearman correlation coefficient $(q)$ & Test value $(t)$ & Value of $p$ \\
\hline $\mathrm{V}_{\max }$ & 21 & 0.55 & 2.89 & $<0.01$ \\
\hline $\mathrm{V}_{\min }$ & 21 & 0.67 & 3.93 & $<0.001$ \\
\hline LAVI & 21 & 0.60 & 3.24 & $<0.01$ \\
\hline \multicolumn{5}{|c|}{ DDD/R 3 months: } \\
\hline $\mathrm{V}_{\max }$ & 59 & 0.39 & 3.18 & $<0.01$ \\
\hline$V_{\min }$ & 59 & 0.40 & 3.34 & $<0.01$ \\
\hline LAVI & 59 & 0.40 & 3.29 & $<0.01$ \\
\hline \multicolumn{5}{|c|}{ DDD/R 6 months: } \\
\hline $\mathrm{V}_{\max }$ & 59 & 0.47 & 4.03 & $<0.001$ \\
\hline $\mathrm{V}_{\min }$ & 59 & 0.49 & 4.28 & $<0.001$ \\
\hline LAVI & 59 & 0.50 & 4.40 & $<0.00$ \\
\hline \multicolumn{5}{|c|}{ VVI/R 3 months: } \\
\hline $\mathrm{V}_{\max }$ & 37 & 0.54 & 3.77 & $<0.001$ \\
\hline $\mathrm{V}_{\min }$ & 37 & 0.59 & 4.32 & $<0.001$ \\
\hline LAVI & 37 & 0.56 & 4.02 & $<0.001$ \\
\hline \multicolumn{5}{|c|}{ VVI/R 6 months: } \\
\hline $\mathrm{V}_{\max }$ & 37 & 0.39 & 2.49 & $<0.05$ \\
\hline $\mathrm{V}_{\min }$ & 37 & 0.37 & 2.39 & $<0.05$ \\
\hline LAVI & 37 & 0.38 & 2.45 & $<0.05$ \\
\hline
\end{tabular}

Sadowski and Wożakowska-Kapłon followed up 28 patients with $\mathrm{AAI} / \mathrm{R}$ and DDD/R pacemakers and did not find elevated BNP values at 6 months [30]. However, Wang et al. in 105 patients with DDD/R and VVI/R pacemakers found a clear relationship between BNP levels, mode of pacing, and NYHA class [31].

In the present study in 117 patients with various types of pacemakers followed up for 6 months initial BNP values were higher in all study groups compared with the controls. Patients with DDD pacemakers showed an increase in BNP values between consecutive time points. In the remaining groups the differences were not significant. The increase in BNP indicating haemodynamic deterioration is encountered in patients with DDD pacemakers in whom right ventricular apical pacing, but not right ventricular outflow tract septal pacing, was used. This mode of pacing is haemodynamically unfavourable, but it is still used due to procedural simplicity and good late effects as regards ventricular lead positioning in the right ventricular apex. An alternative site to apical pacing is the right ventricular outflow tract with active lead fixation. Unfortunately, active fixation leads are not widely used in Kielce. Other results of the present study

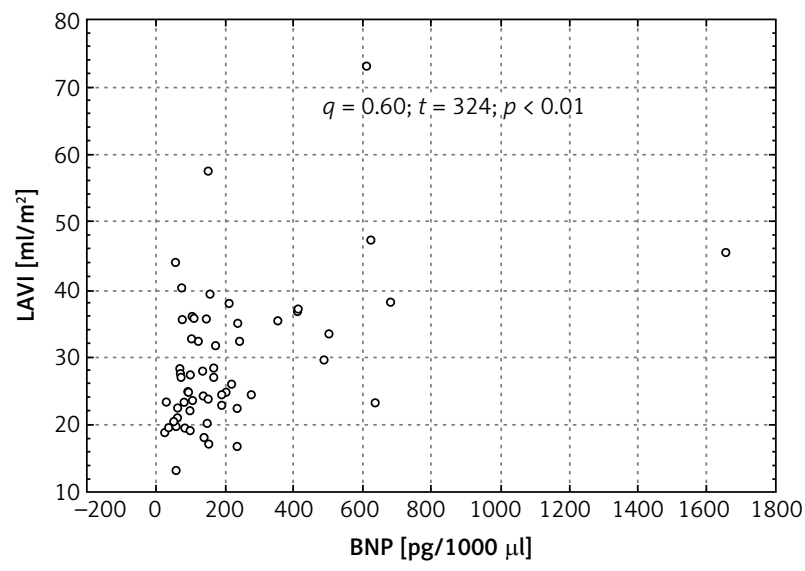

Figure 1. Analysis of correlations between type $B$ natriuretic peptide (BNP) levels in the blood and left atrial volume index (LAVI) in group I (AAI) at 3 months after pacemaker implantation

are concordant with those obtained by other investigators. BNP values are lowest in patients with physiological pacemakers, and highest in patients with VVI pacing. BNP is an early marker of heart failure, and 


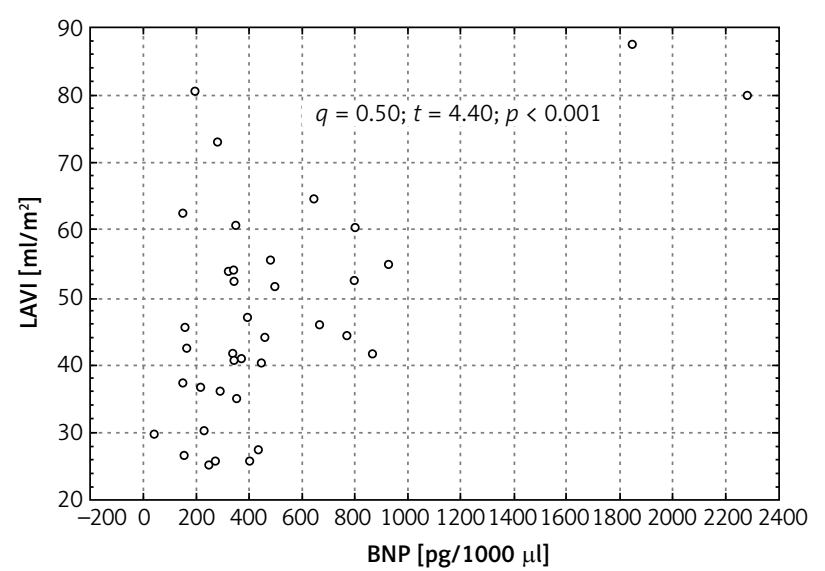

Figure 2. Analysis of correlations between type $B$ natriuretic peptide (BNP) levels in the blood and left atrial volume index (LAVI) in group II (DDD/R) at 6 months after pacemaker implantation

its secretion is stimulated by left ventricular pressure and volumetric overload. These phenomena may be caused by intra-ventricular dyssynchrony due to right ventricular apical pacing. Dyssynchrony with RV pacing has a similar mechanism to left bundle branch block (LBBB) and leads to systolic dysfunction, which causes elevation of left and right atrial pressure. Elevated atrial pressure leads to enlargement of the volume of this chamber. VVI pacing is associated with complete AV dyssynchrony; also, many of the patients with this type of pacing have atrial fibrillation, which results in loss of atrial contraction and significantly reduces cardiac output. A DDD pacemaker enables more physiological stimulation with atrial contraction if the timing of atrial and ventricular contraction is correctly set up. The most physiological pacing is AAI, which provides native ventricular activation.

Echocardiographic measurements of the left atrium are of major importance for cardiovascular assessment and prognosis not only in patients with cardiac diseases but also in healthy subjects. Left atrial dimensions provide important information in patients with left ventricular dysfunction, mitral regurgitation, and atrial fibrillation. Left ventricular volume is a powerful mortality indicator in patients after myocardial infarction. Those with smaller left atrial size and signs of left ventricular systolic dysfunction have a better prognosis than the remaining patients [32-34].

There are studies on the significance of left atrial size in patients with permanent pacemakers. Kubica et al. analysed 114 patients with various types of pacemakers (VVI, AAI, DDD) and found significant differences in left atrial volume on echocardiography in patients with VVI pacing as compared with other types [35]. Nielsen et al. obtained echocardiographic measurements of the left atrium, left ventricle, and left ventricular ejection fraction in patients with $\mathrm{AAI} / \mathrm{R}$

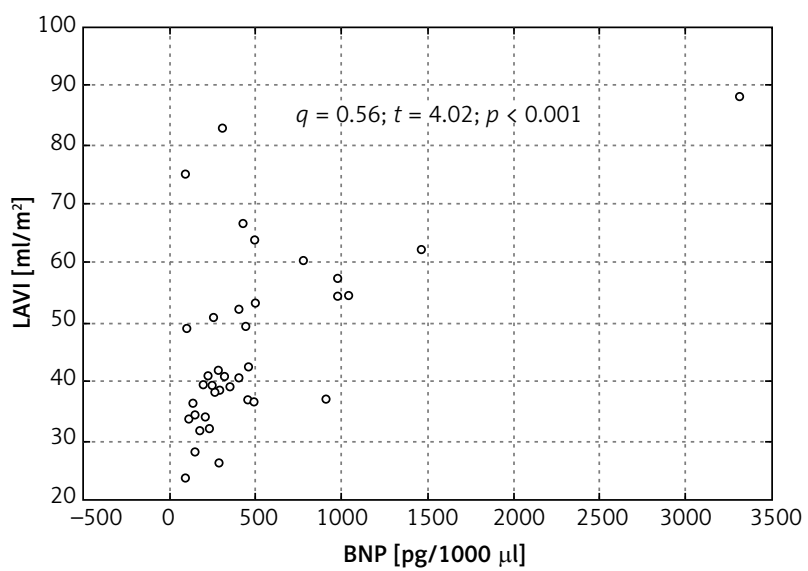

Figure 3. Analysis of correlations between type $B$ natriuretic peptide (BNP) levels in the blood and left atrial volume index $(\mathrm{LAVI})$ in group II (VVI/R) at 3 months after pacemaker implantation

and DDD/R pacing followed up for $2.9 \pm 1.1$ years. Patients with AAI/R pacing did not show any significant differences in echocardiographic measurements of the left atrium, left ventricle, and left ventricular ejection fraction. In patients with DDD/R left atrial size increased significantly whereas LVEF significantly decreased [36]. Psychiari et al. studied 60 patients with known sick sinus syndrome having AAI/R and $\mathrm{DDD} / \mathrm{R}$ pacemakers. Left atrial and left ventricular size did not change, but there were significant differences in tissue Doppler [37].

In the present study the maximum left atrial volume, minimum left atrial volume, and left atrial volume index were significantly higher before the implantation of permanent pacemakers as compared with the controls. After the implantation the values did not change significantly in any of the groups.

Correlation analysis of the relationship between BNP and echocardiographic parameters of the left atrium and left ventricle provides important information on the cardiovascular system in patients with heart failure and diabetes mellitus. Dencker et al. in a study of 33 patients with poorly regulated type 2 diabetes demonstrated significant correlations between BNP and end-systolic left atrial volume. Certain echocardiographic parameters and their correlation with BNP values may be useful in the assessment of patients with glycaemia disorders [38]. Takeichi et al. analysed 92 patients presenting with various cardiovascular diseases: previous myocardial infarction, arterial hypertension, right bundle branch block, and hypertrophic cardiomyopathy. Echocardiography revealed significant correlations between end-diastolic volume, total left atrial fraction, and atrial natriuretic peptide (ANP) in the blood [39]. Koç et al. in a large group of 100 patients with heart failure found signifi- 
cant negative correlations between NT-proBNP and left ventricular ejection fraction [40].

There are no reports in the literature showing correlations between BNP values and echocardiographic dimensions of the left atrium in patients with permanent pacemakers.

In the present study there was a significant correlation between BNP values and echocardiographic parameters. The most significant correlations occurred between BNP and maximum left atrial volume, minimum left atrial volume, and left atrial volume index, mainly at 3 months after DDD/R pacemaker implantation.

The present study in a group of 117 patients demonstrated the usefulness of extended patient evaluation before and after the implantation of permanent pacemakers. After the implantation there are significant haemodynamic changes such as modulations of BNP values and alterations in echocardiographic parameters of the left atrium. It is therefore helpful to analyse these parameters before and after the implantation. Pacemaker check-up should be extended to include measurements of heart failure markers such as BNP. Echocardiographic evaluation should include measurements of left atrial size and function in patients after pacemaker implantation.

\section{Conclusions}

In patients after the implantation of permanent pacemakers there are correlations between BNP values and echocardiographic left atrial parameters, especially in patients with $\mathrm{DDD} / \mathrm{R}$ pacemakers. Left atrial function improves in patients with $\mathrm{DDD} / \mathrm{R}$ pacemakers. Pacemaker check-up should be extended to include BNP measurements and echocardiographic assessment of the left atrium.

\section{Conflict of interest}

The authors declare no conflict of interest.

\section{References}

1. Emdin M, Vittorini S, Passino C, et al. Old and new biomarkers of heart failure. Eur J Heart Fail 2009; 4: 331-5.

2. Luchner A, Möckel M, Spanuth E, et al. N-terminal pro brain natriuretic peptide in the management of patients in the medical emergency department (PROMPT) correlation with disease severity, utilisation of hospital resources, and prognosis in a large, prospective, randomized multocentre trial. Eur J Heart Fail 2012; 3: 259-67.

3. Lam LL, Cameron PA, Schneider HG, et al. Meta-analysis effect of B-type natriuretic peptide testing on clinical outcomes in patients with acute dyspnea in the emergency setting. Ann Intern Med 2010; 11: 728-35.

4. Cheng V, Kazanagra R, Gracia A, et al. A rapid bedside test for $\mathrm{B}$ type peptide predicts treatment outcomes in patients admitted for decompensated heart failure: a pilot study. J Am Coll Cardiol 2001; 37: 386-91.
5. Meisel AS, Krishnaswamy P, Nowak RM, et al. Breating Not Properly Multonational Study Investigators. Rapid measurement of B type natriuretic peptide in the emergency diagnosis of heart failure. N Engl J Med 2002; 347: 161-7.

6. Mueller C, Scholer A, Laule-Kilian K, et al. Use of B type natriuretic peptide in the evaluation and management of acute dyspnea. N Engl J Med 2004; 350: 647-54.

7. McCullough PA, Duc P, Omland T, et al. Breating Not Properly Multonational Study Investigators. B type natriuretic peptide and renal function in the diagnosis of heart failure - an analysis from breathing not properly (BNP) multinational study. Am J Kidney Dis 2003; 41: 571-9.

8. Moe GW, Howlett J, Januzzi JL, et al. N-terminal pro-BNP-type natriuretic peptide testing improves the management of patients with suspected acute heart failure: primary results of the Canadian prospective randomized multicenter IMPROVE-CHF study. Circulation 2007; 115: 3103-10.

9. Mueller C, Laule-Kilian K, Schinaler C, et al. Cost-effectiveness of B-type natriuretic peptide testing in patients with acute dyspnea. Arch Inter Med 2006; 166: 1081-7.

10. Pagel PS, Khel F, Gare M, et al. Mechanical function of the left atrium: new insights based on analysis of pressure-volume relations and Doppler echocardiography. Anestesiology 2003; 98: 975-94.

11. Matsuda Y, Toma Y, Ogawa $\mathrm{H}$, et al. Importance of left atrial function in patients with myocardial infarction. Circulation 1983; 67: 556-71.

12. Thomas L, Levett K, Boyd A, et al. Compensatory changes in atrial volumes with normal aging: is atrial enlargement inevitable ? J Am Coll Cardiol 2002; 40: 1630-5.

13. Hoit BD, Shao Y, Gabel M, et al. Left atrial systolic and diastolic function accompanying chronic rapid pacing-inducted atrial failure. Am J Physiol 1998; 275: H183-9.

14. Pritchett AM, Jacobson SJ, Mahoney DW, et al. Left atrial volume as an index of left atrial size: a population based study. J Am Coll Cardiol 2003; 41: 1036-43.

15. Lang RM, Bierig M, Devereux RB, et al. Recommendations for chamber quantification: a report from the American Society of Echocardiography's guidelines and standards committee and the chamber quantification writing group, developed in conjunction with the European Society of Cardiology. J Am Soc Echocardiogr 2005; 18: 1440-63.

16. Zapolski T, Wysokiński A. Atrial cardiomyopathy as a consequence of atrial fibrillation. Acta Cardiol 2002; 57: 84-6.

17. Stahrenberg R, Edelmann F, Haase B, et al. Transthoracic echocardiography to rule out paroxysmal atrial fibrillation as a cause of stroke or transient ischemic attack. Stroke 2011; 42: 3643-5.

18. Fatema K, Bailey KR, Petty GW, et al. Increased left atrial volume index: potent biomarker for first-ever ischemic stroke. Mayo Clin Proc 2008; 83: 1107-14.

19. Tsang TS, Barnes ME, Gersh BJ, et al. Prediction of risk for first age-related cardiovascular events in an elderly population: the incremental value of echocardiography. J Am Coll Cardiol 2003; 42: 1199-205.

20. Møller JE, Hillis GS, Oh JK, et al. Left atrial volume. A powerful predictor of survival after acute myocardial infarction. Circulation 2003; 107: 2207-12.

21. Takemoto Y, Barnes ME, Seward JB, et al. Usefulness of left atrial volume in predicting first congestive heart failure in patients $>=65$ years of age with well-preserved left ventricular systolic function. Am J Cardiol 2005; 96: 832-6. 
22. Gottdiener JS, Kitzman DW, Aurigemma GP, et al. Left atrial volume, geometry, and function in systolic and diastolic heart failure of persons $>=65$ years of age (the Cardiovascular Health Study). Am J Cardiol 2006; 97: 83-9.

23. Zapolski T, Jaroszyński A, Drelich-Zbroja A, et al. Czynność lewego przedsionka u chorych ze schyłkową niewydolnością nerek bez klinicznie jawnej choroby serca. Prognostyczna wartość wskaźnika objętości lewego przedsionka. Kardiol Pol 2010; 68 (Suppl. III): 277.

24. Available at: http://www.eucomed.org/medical-technology/facts-figures

25. Maisel A, Hollander JE, Guss D, et al. Primary results of the rapid emergency department heart failure outpatient trial (REDHOT): a multicenter study of B-type natriuretic peptide levels, emergency department decision making, and outcomes in patients presenting with shortness of breath. J Am Coll Cardiol 2004; 6: 1328-33.

26. Troughton RW, Prior DL, Pereira JJ, et al. Plasma B-type natriuretic peptide levels in systolic heart failure: importance of left ventricular diastolic function and right ventricular systolic function. J Am Coll Cardiol 2004; 3: 416-22.

27. Troughton RW, Richards AM. B-type natriuretic peptides and echocardiographic measures of cardiac structure and function. JACC Cardiovasc Imaging 2009; 2: 216-25.

28. Cohen-Solal A, Logeart D, Huang B, et al. Lowered B-type natriuretic peptide in response to levosimendan or dobutamine treatment is associated with improved survival in patients with severe acutely decompensated heart failure. J Am Coll Cardiol 2009; 25: 2343-8.

29. Kafkas N, Patsilinakos S, Makris K, et al. Brain natriuretic peptide: a marker of cardiac dysfunction with ventricular or dual-chamber pacing. Acta Cardiol 2011; 66: 589-94.

30. Sadowski M, Wożakowska-Kapłon B. The influence of permanent cardiac pacing on plasma levels of B-type natriuretic peptide in patients with sick sinus syndrome. Cardiology J 2008; 15: 39-42.

31. Wang R, Li X, Jiang W, et al. Observation of blood B-type natriuretic peptide level changes in different periods and different cardiac pacing modes. Chin Med J 2005; 118: 1384-7.

32. Banjamin EJ, D’Agostino RB, Belanger AJ, et al. Left atrial size and the risc of stroke and death. The Framingham Heart Study. Circulation 1995; 92: 835-41.

33. Møller JE, Hillis C, Oh JK, et al. Left atrial volume. A powerful predictor of survival after acute myocardial infarction. Circulation 2003; 107: 2207-12.

34. Beinart R, Boyko V, Schwammenthal K, et al. Long-term prognostic significance of left atrial volume in acute myocardial infarction. J Am Coll Cardiol 2004; 44: 327-34.

35. Kubica J, Stolarczyk L, Krzymińska E, et al. Left atrial size and wall motion in patients with permanent ventricular and atrial pacing. Pacing Clin Electrophysiol 1990; 13: 1737-41.

36. Nielsen JC, Kristensen L, Andersen HR, et al. A randomised comparision of atrial and dual-chamber pacing in 177 consecutive patients with sick sinus syndrome: echocardiographic and clinical outcome. J Am Coll Cardiol 2003; 42: 614-23.

37. Psychiari SN, Apostolou TS, Iiiodromitis EK, et al. DDDR pacing results in left ventricular asynchrony with preservation of ejection fraction and NT-proBNP: a prospecto- ve study in sick sinus syndrome and normal ventricular function. Int J Cardiol 2010; 8: 310-2.

38. Dencker M, Stagmo M, Dorkhan M. Relationship between natriuretic peptides and echocardiography parameters in patients with poorly regulated type 2 diabetes. Vasc Health Risc Manag 2010; 6: 373-82.

39. Takeichi N, Fukada N, Tamura Y, et al. Relationship between left atrial function and plasma level of atrial natriuretic peptide in patients with heart disease. Cardiology 1998; 90: 13-9.

40. Koç M, Bozkurt A, Şahin D, et al. Cutoff values of $\mathrm{Nt}$ proBNP for the prediction of low functional capacity, decreased ejection fraction and cardiovascular event in patients with heart failure. Cardiol J 2009; 16: 43-51.

\section{Address for correspondence:}

\section{Janusz Sielski MD, PhD}

Intensive Care Unit

Świętokrzyskie Cardiology Center

ul. Grunwaldzka 45, 25-736 Kielce, Poland

Phone: +48 413671493

Fax: +48413663336

E-mail: jsielski7@interia.pl 